\author{
Michał Marcin Kobierecki \\ University of Łódź, (Poland) \\ ORCID: https://orcid.org/0000-0002-8180-5710 \\ e-mail: michal.kobierecki@uni.lodz.pl
}

\title{
Recognition of National Football Federations and the Diplomatic Role of FIFA ${ }^{1}$
}

\begin{abstract}
The paper refers to the category of sports diplomacy and aims to investigate the issue of diplomatic subjectivity of international sports organizations, by the example of FIFA and its prerogative to grant membership to national football federations. Such processes on some occasions are connected to political and diplomatic significance, particularly in relation to states without universal international recognition, for whom participation in international sport is an important tool in their struggle for legitimization. The research question that the author attempts to answer is whether membership of national sports organization in the international sports federations can be meaningful from the perspective of the state's endeavors toward securing international recognition. The hypothesis stated that the prerogative of international sports bodies such as FIFA to recognize national sports federations enhances their diplomatic subjectivity.
\end{abstract}

Keywords: FIFA, sport and politics, sports diplomacy, legitimization

\section{Significance of the Topic}

Contemporary international relations are believed to be undergoing a diffusion of diplomacy, which means that apart from nation states there is a number of non-state actors in international diplomacy, including non-governmental organizations (Surmacz, 2015) such as sports bodies. International Sports Federations (IFs) or the International Olympic Committee (IOC), with their global reach, are particularly important here since they are in charge of key international sports events. Because of their global profile and the great popularity that sports generate, they are increasingly attributed with diplomatic significance. This can be observed in various ways, such as the prerogative to select the host of sports events as the governments are usually strongly engaging in such bids, holding negotiations with repre-

1 This work was supported by National Science Centre, Poland [grant number 2015/19/D/HS5/00513]. 
sentatives of states which is a consequence of the fact that they control international sports competition and sports events, have the capability to exert pressure on political authorities of states. In some situations, they might also act as diplomatic forums as their members represent different countries with different political interests. A very important aspect that attaches diplomatic significance to international sports organizations is their capability to recognize national sports organizations such as the National Olympic Committees (in case of the IOC) or national federations in particular sports.

In the media it is often claimed that an IF has recognized a state. Such statements are obviously wrong from the perspective of international law, as only states are capable of recognizing other states. They refer to recognition of national sports organizations, so from the legal perspective it does not have any direct diplomatic consequences. Nevertheless states, those without universal international recognition or whose statehood is questioned by at least part of the international community, or emerging states, strongly engage in their national sports federations' endeavors to be affiliated by IFs (Black \& Peacock, 2013). As Barrie Houlihan (1994) has stated, for many states struggling for recognition in sport is a potential base from which they might try to get into more prestigious forums. This happens despite the fact that some sports federations recognized by international sports organizations in fact represent territories without sovereignty. For example, the IOC has recognized NOCs of Guam, Puerto Rico, American Virgin Islands or American Samoa (Dichter, 2016). Similarly, FIFA has recognized football federations from for example Faroe Islands, New Caledonia or American Virgin Islands, although according to Steve Menary (2007) there is a lot of inconsistency concerning the criteria of FIFA's acceptance of such national federations. There is an obvious difference between territories which are not sovereign states yet which are recognized by international federations and states which struggle for increasing their international recognition through participation in sport. This issue was also addressed within the research.

Recognition of national sports federations by IFs is important because it is impossible for a nation to compete in international sport without it, while the capability of participating in international sport is significant for states from the perspective of their legitimization. It allows states to present their name, flag or emblem to a global audience, also in the countries that do not recognize them. In this context it is worth to mention that for states with questioned statehood it is important not only to compete in international sport, but also to display its national symbols.

The study refers to the concept of soft power, which according to Joseph S. Nye (2008) is the ability to affect others through attraction rather than coercion or payment. Governments employ public diplomacy in order to harvest their soft power resources. This also includes attempts to increase their international profile - through visibility to the global audience, which can be obtained, for example, through participation in international sport. Attempts by certain states to be allowed to compete in international sports events can be therefore perceived through the perspective of their public diplomacy endeavors. 
The aim of the research is to investigate the role of international sports federations in reference to the attempts made by states without universal political recognition to increase their international legitimacy through the possibility to compete in international sport. This relationship is expected to lead IFs to obtain diplomatic subjectivity as a result of the fact, that they become subjects of states' attempts to reach particular political goals. In case of states without universal international recognition it is about becoming integrated with international sport and as a result being able to present their identity to international public during international sports competitions. On the other hand, states which contest their statehood attempt to block recognition of their sports federations by the IFs.

\section{Literature Review}

The study refers to the concept of sports diplomacy. The term is defined in various way by different authors, but most frequently refers to utilizing sport by states for the sake of achieving their international goals (Houlihan, 2004; Merkel, 2017). Sports diplomacy may also refer to the activity of international sports governing bodies and to their relations with states. Such understanding of sports diplomacy has been proposed by Stuart Murray and Goeffrey Pigman (2014), who distinguished two categories of sports diplomacy: the first that refers to using sports by the governments as a diplomatic tool, and second which they described as "international sport as diplomacy" which encompasses diplomatic representation, communication and negotiations between non-state actors that are held as a result of international sport. According to this approach actors such as FIFA or the IOC practice a distinct type of diplomacy. They negotiate with governments, local and regional sports organizations, sponsors, media firms and global NGOs. All this occurs because the practice of international sport requires specialized diplomacy of many actors, and results in the IFs becoming diplomatic actors.

A number of publications has been dedicated to the issue of IFs' recognition of national sports bodies from states without universal international recognition. Most of them refer to divided states like South and North Korea, West and East Germany and communist and nationalist China. Worth mentioning are publications by Guoqi Xu (2008), Udo Merkel (2009; 2015), Heidrun Homburh (2006), Uta Blabier (2009) or Heather Dichter (2016). Recently scholars have also undertaken the issue of Kosovo and its attempts to integrate with international sport (Brentin \& Tregoures, 2016). These and other publications have the tendency to focus on the states' perspectives concerning their political objectives in international relations. Here a different approach is presented, with the focus on the diplomatic subjectivity of IFs, using the example of FIFA. 


\section{Methodology and Hypothesis}

The research presented in the article is a case study that refers to the role of international sports organization in enhancing the international legitimization of states and territories. It has been conducted using the example of the International Federation of Association Football - FIFA, which is regarded as one of the most important sports organizations concerning political and diplomatic significance, alongside the International Olympic Committee (Rofe, 2016). The data has been acquired by archive enquiry conducted by the author in the FIFA Museum in Zurich, Switzerland, and with the use of available scientific publications.

The aim of the study was to answer to the research question whether membership of national sports organization in the IFs can be meaningful from the perspective of the state's endeavors toward securing international recognition. The hypothesis that has been tested states that the prerogative of international sports bodies such as FIFA to recognize national sports federations enhances their diplomatic subjectivity.

\section{Results}

Currently FIFA has more affiliated federations than United Nations member states -211 (FIFA, 2018). Its membership is regarded as a prerequisite of statehood (Keys, 2010; Levermore, 2004). In most cases FIFA's recognition of national football federations proceeds without any controversies, according to the scheme that in a sovereign state a football federation is established, it applies to FIFA for membership which is then granted if it respects FIFA Statutes. In some situations, this process does not go that smoothly though, particularly when the sovereignty of such territory or state is questioned by international community.

The FIFA's problem of becoming politically engaged in reference to the establishment of new states began to rise after World War I, as a result of dissolution of Austria-Hungary and in concerning Irish efforts to play football matches under the name "Ireland" (Lanfanchi et al., 2005). The issue became even more problematic during the Cold War, when a number of states became divided. This refers to China and establishment of People's Republic of China and Republic of China (Taiwan), division of Korea into Republic of Korea and Democratic People's Republic of Korea, and establishment of Federal Republic of Germany and German Democratic Republic. In all those cases states competed in order to be regarded as sole legitimate representatives of respective nations.

Such a situation was obviously posing a problem not only to FIFA, but also to other international sports organizations, particularly to the IOC, which in general adopted a principle according to which one territory/country could only be represented by one federation, whereas the divided states at least initially were perceived according to their former shape. In this matter FIFA turned out to be more elastic than for example the IOC and fairly quickly recognized football federations from the two German and the two Korean states. South Korean federation was affiliated in 1948, the North Korean one 10 years later (Lanfanchi et 
al., 2005). Germany was expelled from international sport including football as a result of the war, but soon Germany's return to international football was on the agenda. West German football officials requested FIFA to allow German teams to play matches against foreign teams. FIFA agreed, but the full membership was not granted to FRG's football federation until Autumn 1950 (Dichter, 2016). The football federation of GDR was recognized two years later (Anderson, 2011).

The so called 'Chinese question' was far more complicated, mostly because of the fact that the hostility between representatives of the two Chinas appeared to be stronger and sports officials from the People's Republic of China and Republic of China did not agree to be members of the same sports organizations, claiming that their countries were sole legitimate representatives of China. In FIFA, initially it was communist China to be represented. However, the President of FIFA Jules Rimet who wanted the organization to remain politically unbiased, in 1953 invited the National Amateur Athletic Federation located in Taiwan to apply for membership. This in fact reflected political tendencies in the international relations, such as Taiwan's membership in the UN. In the following year the FIFA Congress decided to grant membership to the football federation from the Republic of China, despite opposition by the Chinese delegate. During the discussion Rimet claimed that political issues should not be discussed and that the federation from Taiwan had jurisdiction over a determined territory in a sovereign country. The Congress backed his position and China National Amateur Federation was affiliated (Homburg, 2006).

After the sports federation from Taiwan was recognized by FIFA football officials from mainland China tried to exclude it. They submitted such a proposal during the FIFA Congress in 1956. It was not discussed though because of its political character and the Congress rejected it. The situation was fairly similar two years later. At the time the Chinese delegate used the opportunity of confirming the minutes from the previous Congress and demanded that the All China Athletic Federation represented China exclusively. New FIFA President Arthur Drewry intervened asking the Chinese to resume his seat, but the discussion on the proposal to exclude Taiwan was allowed. It was however rejected by the Congress. As a result, on July 8, 1958 the All China Athletic Federation notified its withdrawal from FIFA (Homburg, 2006). The decision was in line with China's withdrawal from most IFs and the IOC, for which Chinese NOC withdrew in September 1958, for similar reasons (Shou-yi, 1958, August 19).

After mainland China withdrew from FIFA its interests were represented by sports officials from other communist countries. For example, in 1960 a proposition to exclude the federation from Taiwan was submitted by the Bulgarian federation. It was however rejected by a majority of votes. The situation of the Republic of China in international sport deteriorated from 1970s. In FIFA it was connected to the affiliation of many new federations resulting from decolonization and their more positive attitude toward the PRC. The issue was discussed during FIFA Congress in 1974, but the Executive Committee succeeded in increasing the majority necessary to exclude Taiwan to $75 \%$. The proposal failed but 
a growing support for the PRC was clearly visible. The issue was back on the agenda during the Congress in 1978 in Buenos Aires. It decided to entrust the Executive Committee to make a decision on the Chinese question, which in turn began negotiations with the two parties. In 1979 a compromise was achieved which meant that the federation from Taiwan maintained its membership, but its name was changed into "The Chinese Taipei Football Association" and it could not use the national symbols of the Republic of China, whereas the Football Association of the People's Republic of China was re-admitted (Homburg, 2006; Executive Committee Decision of 13 October 1979 regarding the China Question, 1979). For this to happen it was essential that both Chinese states changed their original attitude. In the case of China, it meant an agreement to tolerate membership of Taiwan in the same international sports organization, while in the case of Taiwan to agree to a changed name of its federation. This situation illustrates that in some situations it is extremely important to be member of international sports organization and to prevent a contested state from having such membership. It is connected with the fact that participation in international sport makes the global audience acquainted with a country, its name and flag, thus increasing its international legitimacy. Since the divided states have been competing for international legitimacy, the significance of integration with international sport has been natural.

A similar situation, but much more contemporary, referred to Kosovo and the attempts of its football federation to be recognized by FIFA. This state in 2008 declared independence from Serbia which did not accept the secession. As a result, securing universal international recognition became one of Kosovo's key goals in international relations. Its initial endeavors to reach this goal were unsuccessful though, for example Kosovo failed to become a United Nations member state. It has therefore been decided that diplomatic activity of Kosovo should focus on non-state actors. The country has applied for membership in multilateral organizations (Brentin \& Tregoures, 2016), including attempts by its sports organizations to be affiliated to IFs.

Within wider attempts to join international sport the possibility of competing in football was regarded as particularly important. Shortly after the declaration of independence, the Football Federation of Kosovo applied to FIFA for affiliation (FIFA, 2008, May 27). FIFA Executive Committee decided that Kosovo did not comply with the prerequisite that only "an independent state recognized by the international community" may be admitted (FIFA, 2008, October 24). This argument revealed FIFA's inconsistency since non-independent territories such as Faroe Islands or New Caledonia or Faroe Islands had recognized football federations by that time, although none of them was recognized soon after foundation.

FIFA's decision made sports officials from Kosovo to adjust their tactics and applied for the possibility of the teams from Kosovo to play friendly matches against teams from FIFA member federations (Brentin \& Tregoures, 2016). FIFA's response in 2011 was negative, although in fact it simply sustained the decision by the European confederation UEFA (FIFA, 2011, March 3; FIFA, 2011, October 21). Nevertheless, already in 2012 FIFA changed its previous decision and allowed its members to play against teams from Kosovo, although 
initially there was a number of restrictions, for example referring to the use of national symbols of Kosovo (FIFA, 2013, February 6). Some of them were abolished two years later; for example, teams from Kosovo were allowed to have the word "Kosovo" on their uniforms and a symbol of a star of the size of letter "o" in "Kosovo". Those were some of the results of meetings between FIFA President Joseph Blatter with political leaders and sports officials from Serbia and Kosovo. New decisions were also taken at the time of the final stage of negotiations between the two countries under the auspices of the EU (FIFA, 2014, January 13a; FIFA, 2014, January 13b; FIFA, 2014; Brentin \& Tregoures, 2016).

The final settlement of the situation of Kosovo in international football took place in 2016. On May 3 despite Serbia's resistance UEFA granted full membership to the Football Federation of Kosovo (Montague, 2016, May 3; Payerhin, 2016). FIFA did the same on May 13 (The Economist, 2016). Since then Kosovo was allowed to normally compete in international football, beginning with the FIFA World Cup 2016 qualifications (FIFA, 2016, September 15). For Kosovo it obviously had great significance concerning its international legitimization, since capability of participating in international sport gives an opportunity of presenting the state, its name and national symbols to global audience. Importance of such symbols was aptly described by Kosovo's acting Minister of Foreign Affairs, Petrit Selimi concerning recognition by the IOC, who said that "marching in Rio de Janeiro with a Kosovo flag for the first time ever is a pinnacle of state building and is as important as other forms of recognition" (LSE, n.d.). It is about making people acquainted with the country, its name and the flag, hoping that such familiarity would foster diplomatic recognition.

It is important to note that situations in which national sports federations and sometimes even governments make an effort in order to have the possibility of competing in international sport are not typical and mostly refer to countries with questioned sovereignty or international recognition. If there are no doubts about that, IFs usually recognize federations from such countries very quickly. For example, South Sudan became independent in 2011 and its football federation became a FIFA full member in 2012 (FIFA, 2012, August 8). In this case, in order to make the whole procedure quicker, FIFA has changed its internal regulations concerning the possibility to apply for membership two years after its recognition by the relevant continental confederation (FIFA, 2012, March 30; FIFA Congress to tackle first reforms, 2012). An interesting case referred to states established after the collapse of the Soviet Union. Baltic states' football federations were granted provisional membership and allowed to compete in World Cup qualifications only a couple of months after they declared independence. On the other hand, other post-Soviet states, because of only partial diplomatic recognition, were not recognized by FIFA and initially were to compete under the former association of USSR (Blatter, 1992). Those situations show us that in most cases FIFA simply copies the decision of the international community, and often a default prerequisite of recognizing a national federation is its state's membership in the UN. The case of Kosovo has indicated on the other hand, that it is not always an essential condition. 
The issue of contested states' attempts to be allowed to compete in international sport becomes more complicated after considering that IFs such as FIFA affiliate federations representing territories without sovereignty. For example, the football federation from Palestine is a FIFA member. In May 1995 it was granted provisional membership (BosniaHerzegovina and Palestine provisional members, 1995) and in 1998 became a full FIFA member (FIFA, 1998, July 29). These developments are one of the effects of an agreement between the Palestine Liberation Organization and Israel in early 1990s.

Another FIFA member not representing a sovereign state is Gibraltar, an overseas territory of Great Britain. Its international status was further complicated by the fact that it is the subject of a territorial dispute with Spain. Despite all that, the football federation from Gibraltar applied for FIFA membership already in 1991 - after FIFA recognized Faroe Islands in 1990. FIFA responded negatively as it wanted to avoid political tensions between Spain and Great Britain. In 2000 Gibraltar once again applied for recognition by FIFA, but after an intervention by Spain both FIFA and UEFA did not agree. Moreover, both sports bodies changed their statutes by including UN membership as a prerequisite of recognizing national football federations. Despite that, in 2003 Court of Arbitration for Sport (CAS) decided that Gibraltar's application should be examined under former statutes (Kaya, 2016). In the end Gibraltar's application for membership was accepted by FIFA in 2016 after another award was rendered by CAS, according to which FIFA Council was ordered to submit Gibraltar's application to FIFA Congress, which shall admit Gibraltar Football Association as a FIFA member (FIFA, 2016, May 3).

\section{Discussion and Findings}

Situations of states without full international recognition and their attempts to compete in international sport suggest that IFs such as FIFA have political and diplomatic significance in international relations, since their decisions affect states and their capability of building and increasing their international legitimization. Nevertheless, it is doubtful whether such status is actually desirable by sports federations, which most often declare universality and refrain from political engagement. By contrast, situations when a sports federation from a state without universal international recognition applies for membership make IFs impossible to remain politically neutral, since both recognizing such national federation despite objection by some states or refusal to do so always means backing one side of such political conflict. Moreover, contexts of such situations often force international sports organizations to engage in negotiations with a number of stakeholders, including governments and political leaders.

The evoked cases of contested states struggling for the possibility of competing in international sport, what is inextricably bound with the need of granting recognition by IFs to national sports federations, suggests a great significance of not only being able to compete internationally, but also to be able to use national symbols or official names of the states. In 
the case of Taiwan, not using the word "China" by its football federations was one of PRC's conditions for joining FIFA, while teams from Kosovo initially were not allowed to use the country's name and national symbols, which symbolically questioned its sovereignty. Such solutions may serve as a compromise between a state desiring to compete in international football and governments contesting its statehood.

Another observation from FIFA's decisions concerning membership of some contested states refers to paradox of international recognition and capability to compete in international sport. FIFA, in order to refrain from political engagement, uses recognition by the international community a prerequisite of granting membership to a national football federation. This could suggest that recognition by FIFA and other sports bodies is an effect of international recognition. Moreover, such approach theoretically protects FIFA and other IFs from political engagement. However, there is also a question whether international recognition should be equated with being a UN member state. For example, Kosovo has been formally recognized by more than 100 states but was not granted UN membership yet. Regardless of such considerations, there is a number of cases when national sports federations were recognized by FIFA before their states became UN members, or even without it. Such states received the possibility to compete in international sport and to present themselves to international audience, thus facilitating their international legitimization. In such situations, recognition by IFs the from perspective of these states is a tool toward international recognition and at the same time a public diplomacy endeavor aimed to increase the awareness of their existence among the global public. From this perspective, capacity to participate in international sport is the soft power asset, whereas IFs such as FIFA act as external stakeholders of such public diplomacy.

A controversy refers to FIFA membership of territories without sovereignty. This raises a question concerning one of the main assumptions of this study - that membership in an international sports organization is important for contested states as it is one of the prerequisites of statehood. If territories without sovereignty may also compete in international sport, why should it matter for states struggling for international recognition? The difference between those situations refers to objectives of participation in international sport. In case of territories it appears to be deprived from the context of struggling for legitimization and applications for membership from federations from such territories are usually supported by states controlling those lands, whose motivation might be connected with respect of distinctive identity of particular territories, of course unless they had an ambition of gaining independence. The cases of contested states are far different and there are virtually always objections by some states against their recognition by a sports federation. Attempts by the divided countries during the Cold War to be able to compete in international sport were supported by their political allies, for example the PRC was backed by communist countries, similarly as East German attempts to have their football federation recognized by FIFA. Kosovo's attempts to integrate with international football was objected by Serbia. In such cases the political significance of decisions by FIFA and other IFs is the greatest, which leads to their strongest diplomatic engagement. 


\section{Conclusions}

The study aimed to investigate the diplomatic significance of FIFA concerning its decisions about recognizing national football federations. Particular attention was dedicated to states without universal international recognition, as for them capability of competing in international sport appears to be a significant legitimization tool. The evoked situations when FIFA had to cope with such applications by federations from contested states appear to verify the hypothesis, according to which the prerogative of international sports bodies such as FIFA to recognize national sports federations enhances their diplomatic status. This stems from the fact that participation in international sport may be considered as a soft power asset. As a result, IFs which have the jurisdiction over international sport obtain the roles of external public diplomacy stakeholders. Despite their declared universality and political neutrality, such situations force them to take a political stance and to engage in international negotiations, also with representatives of states' authorities. All this leads to a conclusion that sports bodies such as FIFA should be regarded as international diplomatic actors.

\section{References}

Anderson, S. (2011). "Soccer and the failure of East German sports policy”. Soccer \& Society, 12(5), 652-663. Balbier, U.A. (2009). “'A Game, a Competition, an Instrument?': High Performance, Cultural Diplomacy and German Sport from 1950 to 1972”. The International Journal of the History of Sport, 26(4), 539-555. Black, D., Peacock, B. (2013). “Sport and Diplomacy”. In A.F. Cooper, J. Heine \& R. Thakur (Eds.), The Oxford Handbook of Modern Diplomacy (708-726). Oxford: Oxford University Press.

Blatter, J.S. (1992). "FIFA gives right of way to politics". FIFA News, 2, 1.

Bosnia-Herzegovina and Palestine provisional members. (1995). FIFA News, 6-7, 2.

Brentin, D. \& Tregoures, L. (2016). “Entering Through the Sport's Door? Kosovo's Sport Diplomatic Endeavours Towards International Recognition”. Diplomacy \& Statecraft, 27(2), 360-378.

Dichter, H.L. (2016). "Sporting Relations: Diplomacy, Small States, and Germany's Post-war Return to International Sport”. Diplomacy \& Statecraft, 27(2), 340-359.

Executive Committee Decision of 13 October 1979 regarding the China Question. (1979). FIFA News, 197, 597.

FIFA (2018). Associations. Retrieved from https://www.fifa.com/associations/index.html.

FIFA Congress to tackle first reforms. (2012). FIFA World, 14.

FIFA. (1998, July 29). Media Release. Welcome to FIFA's New Members. Zurich: FIFA Museum Archives.

FIFA. (2008, May 27). Media Info. FIFA Executive Committee Meeting in Sydney. Unanimous Support for

“6+5” Objectives. FIFA Club World Cup to Be Played in the UAE (2009 \& 2010) and in Japan (2011 \& 2012). Zurich: FIFA Museum Archives.

FIFA. (2008, October 24). Media Info. FIFA Executive Committee. FIFA's Finances Solid Despite International Crisis. Zurich: FIFA Museum Archives.

FIFA. (2011, March 3). Media Release. FIFA Executive Committee Meeting. Financial Report Presented and Decisions Taken on Competition Hosts and 2014 FIFA World Cup ${ }^{\mathrm{Tw}}$ Slots. Zurich: FIFA Museum Archives. FIFA. (2011, October 21). Media Release. FIFA Executive Committee Meeting. FIFA Confirms Its Strong 
Commitment to Reforms by Adopting Governance Structures and Road Map. Zurich: FIFA Museum Archives.

FIFA. (2012, August 8). Media Release. Welcome to South Sudan. Zurich: FIFA Museum Archives.

FIFA. (2012, March 30). Media Release 2012-018. Zurich: FIFA Museum Archives.

FIFA. (2013, February 6). Circular no. 1342. Zurich: FIFA Museum Archives.

FIFA. (2014). FIFA Activity Report 2013. 64 $4^{\text {th }}$ FIFA Congress. São Paulo, 10 and 11 June 2014. Zurich: FIFA Museum Archives.

FIFA. (2014, January 13a). Circular no. 1402. Zurich: FIFA Museum Archives.

FIFA. (2014, January 13b). Media Release. FIFA Emergency Committee Confirms Friendly Matches Involving

Clubs and Representative Teams of Kosovo. Zurich: FIFA Museum Archives.

FIFA. (2016, May 3). Circular no. 1538 to the Members of FIFA. Zurich: FIFA Museum Archives.

FIFA. (2016, September 15). Media Release. Brazil Surge Back, Gibraltar and Kosovo Make History. Zurich:

FIFA Museum Archives.

Homburg, H. (2006). "FIFA and the "Chinese Question", 1954-1980: An Exercise of Statutes". Historical Social Research, 31(1), 69-87.

Houlihan, B. (1994). Sport and International Politics. New York: Harvester Wheatsheaf.

Houlihan, B. (2004). "Politics and Sport". In J. Coakley \& E. Dunning (Eds.), Handbook of Sports Studies

(213-227). London: Sage.

Kaya, C. (2016). "Accession of Gibraltar to UEFA: How did Spain lose influence?". Soccer \& Society, 5-6.

Keys, B. (2010). “International relations”. In S.W. Pope \& J. Nauright (Eds.), Routledge Companion to Sports History (248-267). Abingdon: Routledge.

Lanfanchi, P., Eisenberg, C., Mason, T. \& Wahl, A. (2005). 100 Years of Football: The FIFA Centennial Book. London: Weidenfeld \& Nicolson.

Levermore, R. (2004). “Sport's role in constructing the 'inter-state' worldview”. In R. Levermore \& A. Budd

(Eds.), Sport in international relations: An Emerging Relationship (16-30). London: Routledge.

LSE (n.d.). Petrit Selimi: "The sight of our athletes marching in Rio de Janeiro will be the pinnacle of statebuilding for Kosovo”. Retrieved from https://blogs.lse.ac.uk/europpblog/2016/03/29/petrit-selimi-thesight-of-our-athletes-marching-in-rio-de-janeiro-will-be-the-pinnacle-of-state-building-for-kosovo/. Menary, S. (2007). "When is a National Team not a National Team". Sport in Society, 10(2), 195-204.

Merkel, U. (2009). "Sport, Politics and Reunification - A Comparative Analysis of Korea and Germany". The International Journal of the History of Sport, 26(3), 406-428.

Merkel, U. (2015). "The Politics of Sport and Identity in North Korea”. In F. Hong \& L. Zhouxiang (Eds.), Sport and Nationalism in Asia: Power, Politics and Identity (104-118). London: Routledge.

Merkel, U. (2017). "Sport as a foreign policy and diplomatic tool”. In A. Bairner, J. Kelly \& J. Woo Lee (Eds.), Routledge Handbook of Sport and Politics (28-38). Abingdon: Routledge.

Montague, J. (2016, May 3). “UEFA’s Recognition of Kosovo Angers Serbs”. New York Times. Retrieved from https://www.nytimes.com/2016/05/04/sports/soccer/uefa-recognizes-kosovo-paving-way-forfifa-membership.html?_r=0.

Murray, S. \& Pigman, G.A. (2014). "Mapping the relationship between international sport and diplomacy”. Sport in Society, 17(9), 1098-1118.

Nye Jr., J.S. (2008). “Public Diplomacy and Soft Power”. Annals of the American Academy of Political and Social Science, 616(1), 94-109.

Payerhin, M. (2016). Nordic, Central, and Southeastern Europe: The World Today Series 2016-2017. Lanham: Rowman \& Littlefield Publishers. 
Rofe, J.S. (2016). “Sport and Diplomacy: A Global Diplomacy Framework”. Diplomacy \& Statecraft, 27 (2), 212-230.

Shou-yi, T. (1958, August 19). Letter to IOC Members and NOCs. IOC Archives, Lausanne.

Surmacz, B. (2015). Ewolucja wspótczesnej dyplomacji. Aktorzy, struktury, funkcje. Lublin: Wydawnictwo UMCS.

The Economist. (2016). Kosovo's Recognition by FIFA Is a Step Towards International Legitimacy. Retrieved from http://www.economist.com/blogs/gametheory/2016/05/sport-and-statehood.

Xu, G. (2008). Olympic Dreams: China and Sports 1895-2008. Cambridge: Harvard University Press. 